\title{
The linkage between strategic human resource management, innovation and firm performance
}

\author{
Hadi Minavand ${ }^{1,}$ Zahra Lorkojouri ${ }^{2}$ \\ I\&2 International Business School/ Universiti Teknologi Malaysia (UTM)
}

\begin{abstract}
Innovation is regarded as the driving force of rapid changes in the modern world and one of the key success factors in the competitive market. Firms have to innovate, to survive in the market. The disruptive wave of innovation every year makes so many businesses disappear from the market. On the other hand, successful implementation of innovation programs can guarantee profitability and an acceptable overall performance for any firm. In addition, strategic planning for human resources plays a key role in innovation practices and helps firms achieve their long-term objectives. This paper intends to assess a linkage between strategic human resource management, innovation, and overall performance within a firm. In order to examine such a linkage, an online survey was applied and data were collected from 54 managers of product development projects in Malaysian manufacturing companies. Analysis of the collected data using correlation analysis techniques proved that there is a strong correlation between the three mentioned concepts.
\end{abstract}

Keywords -Innovation, SHRM, Firm Performance

\section{INTRODUCTION}

The current century is the era of unbelievable rapid changes which result in an increasing global competition. Every year, some new competitors emerge in the market and some others disappear. There are several reasons why some businesses fail to compete in the market. It is almost evident that the ability of a business to innovative new products has an undeniable effect on its long-term performance in the market (Eslami \& Nakhaie, 2011) [1]. Nowadays innovation is considered as the heart of any business because when a company stops innovating, it looks like that its heart stops beating and the company's business has no choice except to die. Innovation provides the opportunity for firms to improve the quality of services and products, increase process efficiency, reduce costs, meet the changing demands of the market, increase profit, gain a bigger market share and differentiate themselves from the other competitors (Chen \& Huang, 2009) [2]. It is proven that organizations with a higher level of innovativeness are more successful in responding to the increasing demands of changing environments; also, they perform better in developing essential capabilities which allow them to achieve a higher market share (Montes et al., 2004) [3].

Within the last decade, a new phrase emerged in the world of innovation: disruptive innovation. This phrase addresses those innovation activities that help to create a new market and value chain, and unintentionally disrupts an existing market or value chain, and displaces an earlier technology. Disruptive innovation actually stands against sustaining innovation which does not create new value chain or market and rather only tries to evolve the existing markets with higher value. This kind of innovation allows the firms to compete upon each other's sustaining improvement. Anyway, the new approach to innovation changed the classic rules of business, including marketing methods and the ways of strategic thinking. For example, the conventional strategic disciplines mostly emphasized on one of the three common strategies: cost leadership, differentiation, and customer intimacy (generally known as Porter's generic strategies), whereas disruptive innovation normally competes in all the mentioned areas at the same time (Downes \& Nunes , 2013) [4]. In other words, in the competitive environment built by the new wave of innovation, firms' business strategy is forced by the market and they have not the freedom to take a single strategy to compete in the market. On the other hand, such a competitive environment strongly requires creative people and proper human resource policies. Innovation programs strongly depend on skills, knowledge, and the degree of commitment as the essential factors needed for value creation mechanism (Youndt et al., 2006) [5]. Development of human resource strategies is an essential action wherever a group of people work together to achieve common goals (Sharma, 2012) [6]. It is clear that in order to achieve long-term objectives firms need to manage their human resources strategically; the need for strategic human resource management (SHRM) emerges from here. Any recruitment, training and organizing activity related to human resources should be implemented based on a strategic plan which is normally aligned with the firm's overall business strategy.

After reviewing the above arguments, it seems that there is a link between a firm's strategic human resource management, its innovative practices and the extent to which the firm shows a successful performance in achieving its strategic goals. 


\section{CONCEPTUAL FRAMEWORK}

The current study intends to examine a triple linkage between an organization's strategic human resource management, its innovation-related practices and the extent to which the organization has achieved success in its overall performance. In order to examine such a linkage, in this section a conceptual framework will be presented and later, proposition of hypotheses, construction of the questionnaire, and analysis of collected data all will be done based on this framework.

Fig. 1-1 illustrates the conceptual framework of current study. As the figure shows, three concepts of SHRM, innovation and firm performance form the foundation of this study. Assessing the linkage between these three elements is the study's main purpose.

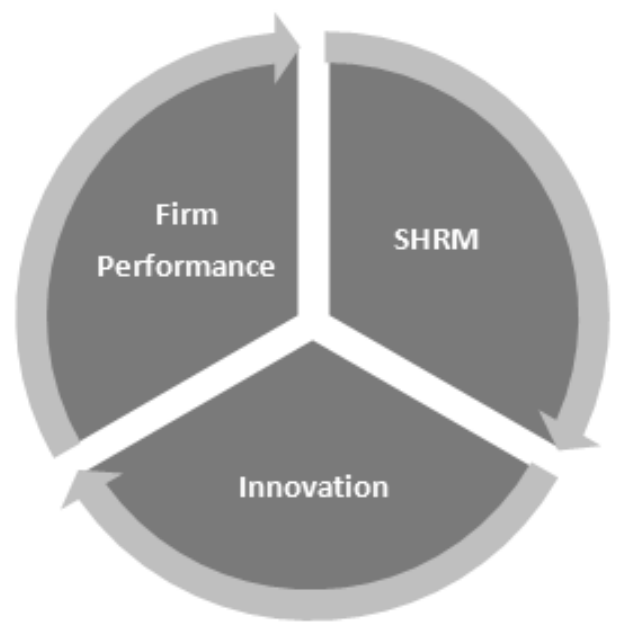

Figure1 The conceptual framework

According to the above scheme, it is expected to find a positive link between each two concepts independently. Based on this framework, three hypotheses will be proposed in the following sections.

\section{LITERATURE REVIEW}

In alignment with the conceptual framework, this section reviews the literature of studies which have assessed the relationship between any two out of the three concepts introduced in the previous sections.

\section{1- Strategic Human Resource Management \& Innovation}

In a continually changing market environment, human resources are regarded as one of the most important sources of competitive advantage. ÇALIŞKAN (2010) [7] believes that HR systems can easily contribute to sustainable competitive advantages by facilitating the development of firms' specific competencies. In his opinion, strategic human resource management deals with creating a clear linkage between the strategic goals of the firm and its human resource policies. Scarbrough (2003) [8] argues that when firms start to develop a new product or improve the quality of services, they need a high level of motivation and competencies among their human resources to generate innovative ideas, develop innovation practices to provide new opportunities.

HR activities can change the capacities, attitudes and behaviors of all the staff in order to satisfy strategic objectives of the organization (Collins and Clark, 2003) [9]. Such activities have an undeniable effect on providing required conditions which lead individuals to implement innovative programs (Scarbrough, 2003) [8]. Firms can pursue different strategic human resource activities such as planning, hiring, training, monitoring and rewarding as required tools to motivate employees, enhance their level of commitment to the firm and encourages them to participate in strategic thinking and innovation (Laursen and Foss, 2003) [10].

Chen \& Huang (2009) [2] argues that strategic human resource practices can highly affect a firm's innovation performance. According to them, when firms decide to develop their innovative activities, they normally face with relatively higher levels of uncertainty, risk and instability in the process of innovation. They need more creative staff who are enough flexible, risk-taker and tolerate ambiguity and uncertainty (Madsen and Ulhøi, 2005) [11]. Hence, firms are required to focus more and more on such competencies in their staffing programs. When firms apply creative capacities and innovative competencies as selection and recruitment criteria, their staff are likely to produce diversity of new ideas and show more innovative behaviors. An effective staffing makes employees huge sources of innovative ideas within the firm's journey toward innovation. 
Training of human resources facilitates employees' exposure to different fields of knowledge and fertilizes creative ideas (Jaw and Liu, 2003) [12]. Organizations try to provide employees different training programs to improve their knowledge, skills, and also the innovative capability required for fulfilling their tasks (Mumford, 2000) [13]. Through training programs, firms can enhance the overall level of organizational expertise as a necessary tool for the innovation process (Weisberg, 2006) [14]. Funding for training programs can develop employees' skills and expertise at all organizational levels which are likely to become an endless source of new ideas for further innovation (Torraco and Swanson, 1995) [15]. In addition, innovation process needs employees with a high level of participation and involvement. Firms may enhance the employees' level of participation and involvement through granting them the opportunity to solve some problems and encouraging them to participate in decision-makings that affects their workplace conditions. A high level of involvement and participation can provide the conditions to persuade employees to generate innovative ideas and exchange their knowledge within the process of innovation and, in turn, enhance the chance of success for innovative activities (Jiménez-Jiménez and Sanz-Valle, 2005) [16]. Because of the lengthiness, uncertainty and complexity of innovation processes, firms should provide a formal appraisal mechanism to evaluate and measure innovation outputs. A positive pressure exerted by an appraisal system creates challenges, results in the "feelings of achievements", and plays the role of an important motivating factor for the staff (Jaw and Liu, 2003) [13]. Performance appraisal enhances the employees' level of motivation and encourages them to engage in innovative programs, and facilitates achievement of desirable outcomes (Jiménez-Jiménez and Sanz-Valle, 2005) [16]. Furthermore, recognizing the successful performances of individuals and teams with rewarding them also encourages innovation. Recognition and rewarding are essential actions which can motivate employees undertake challenging works and generate more innovative ideas and develop more new products or services (Mumford, 2000) [13].

The above literature review suggests that organizations can apply strategic human resource systems to influence the innovative behaviors of employees and provide better conditions to develop innovation programs. Using effective strategic human resource practices in the areas of selecting, hiring, training, participation, recognition and rewarding firms can enhance their capabilities in introducing some new products, services, and processes in order to remain competitive in the market. All in all, the above arguments lead us to propose our first hypothesis as follows:

Hypothesis1: "Strategic human resource practices positively relate to innovation performance".

\section{2- Innovation \& Firm Performance}

Innovation approach inside a firm can considerably affect its performance in several dimensions. In particular, the literature focuses on four different dimensions of performance to assess the effect of innovation on firm performance. These dimensions consist of production performance, innovation performance, financial performance and market performance (Yilmaz et al., 2005) [17]. Innovation considerably affects corporate performance by improving the firm's market position which is accompanied by the competitive advantages (Walker, 2004) [18]. A large number of researchers focusing on the relationship between innovation and performance claim that the higher innovativeness within a firm normally results in an improved corporate performance (Wu et al., 2003) [19]. But these studies are mostly conceptual in nature and normally focus only on a single dimension of performance rather than considering all four types already mentioned. The majority of these studies embraces a positive association between a firm's innovative activity and its overall performance, whereas some of them indicate a negative link or even no link between the mentioned issues (Chandler \& Hanks, 1994 ; Subramanian \& Nilakanta, 1996) [20] [21].

According to Miller (2001) [22] firms often look for technological innovation in order to gain competitive advantage in their existing or future markets. Therefore, all these efforts need to be supported by organizational and marketing measures. But researchers sometimes neglect one of them whereas both the measures are equally necessary for the effective operation and general growth of a firm. (Gunday et al., 2011) [23]. Relatively few researches on innovation capabilities support both organizational and marketing innovations. In general, more innovative firms put more emphasis on leadership and management techniques in order to achieve sustainable levels of successful performance (Guan\& Ma, 2003) [24].

Walker (2004) [18] compared the effects of product and process innovations in the performance of a firm. He suggested that particular types of product improvements are associated positively with firm growth.

Lin and Chen (2007) [25] found an association between innovations and increased sales; they claimed that organizational innovations in comparison with technological innovations seem to be a more vital factor affecting total sales. Moreover, Johne and Davies (2000) [26] suggested that innovation in marketing techniques can result in sales increase by increasing market demand and consequently returns additional profit to the firm.

Also, Oke (2007) [27] within an empirical study of some British firms proved that different types of innovations are positively related to the overall firm performance. 
The above discussions, lead us to propose that all types of innovations positively affect firm's performance. Accordingly, our second hypothesis are allocated to the relationship between innovations and firm performance:

Hypothesis 2: "Innovation practices in a firm positively relate to the firm's overall performance".

\section{3- Strategic Human Resource Management \& Firm Performance}

Strategic HRM is a planned pattern of workforce deployment and a set of activities which intends to enable the firm to meet its long-term goals and objectives (Noe et al. ,2007) [28]. Employees' degree of involvement and the extent to which they participate in core decision-making, the partnership undertaken by departments of HRM, the formality and specificity that HRM departments need to plan and implement are some issues with which SHRM deals to ensure that human resources contribute to achieving long-term objectives of a business (Darwish, 2009) [29].”

In a comprehensive review of the literature, Delery and Doty (1996) [30] identified three main categories of researchers and theorists who focused on developing the theory of SHRM. They named the first group as 'Universalists' because of their focus on identifying the best SHRM practice and policies. They argued that "this group of researchers proposes that some HR practices are always better and more proper than others and all firms should try to adopt these best practices". This point of view underlies the current interest in developing high performance work practices. Thus, it could be assumed that the adoption of some specific SHRM practices is likely to cause an increase in firm performance (Darwish, 2009) [29].

The second group of researchers identified by Delery and Doty (1996) [30] comprises those who adopted a contingency approach. Keeping in line with the early contingency perspective of organizational theory, these researchers believe that the success of HRM practices contingently depends on achieving a match between HR policies and other dimensions of the organizational policies. For example, researchers who adopted this perspective have stated that different HR policies may be needed at different steps of organizational life cycle.

Configuration-oriented theorists were the third identified group of SHRM researchers. Delery and Doty (1996) [30] argued that this approach is more complicated and consists of those researchers who intend to identify configurations, or specific patterns of parameters which are claimed to have the maximum degree of effectiveness. These researchers are also known as more theoretical-based theorists and the majority of the phenomena identified by them may not be empirically observable.

A common issue in all the three perspectives of SHRM theory is the assumption that strategic human resource practices are considerably linked to firms' overall performance. However, despite the issue that the literature is enough rich with posits that HRM and also SHRM are linked to organizational performance, few of them have examined this claim empirically and the theoretical base upon which these links are built are inadequate (Darwish, 2009) [29].

Accordingly, it is important to achieve a better understanding about the role of SHRM practices in enhancing and sustaining firms' overall performance and creating competitive advantages for them. This could be done by further theoretical development which is based on empirical evidences (Jing and Huang, 2005) [31].

In conclusion, the arguments of this section lead us to examine the idea that those organizations which follow SHRM practices, achieve a better performance in comparison with organizations that are reluctant to implement SHRM. Hence, our third hypothesis is proposed as follows.

Hypothesis 3:"Strategic human resource practices in a firm positively relate to the firm's overall performance".

\section{METHODOLOGY}

Online survey was selected as the method of data collection. The questionnaire was uploaded on the internet and its link was sent to the respondents using social networks, email, and other online media. Managers of product development projects in Malaysian manufacturing companies were selected as the target population. Online communities of project managers helped us to identify our respondents and request them to assess the strategic human resource management, innovation, and overall perforce of their firms by answering some questions. Finally, 54 project managers from different industries answered the questionnaire. $77.8 \%$ of respondents $(\mathrm{n}=42)$ were male and the total average of respondents' experience was 12.3 years.

The survey instrument of the current study was a Likert-scale questionnaire with five choices from 'strongly disagree' to 'strongly agree'. Four questions were allocated to each concept and totally 12 questions were designed to explore respondents' viewpoints in terms of SHRM, innovation and the overall performance of the companies to which they belonged. A pilot test with 15 participants was conducted to ensure about the reliability of the questionnaire, and its validity was checked using factor analysis in SPSS. 


\section{DATA ANALYSIS}

The collected data were analyzed using SPSS. In the first step, dimension reduction techniques were applied to combine the items related to each concept and introduce one single variable. Consequently, three interval variables were created to continue the analysis. The next step was selecting a proper method to assess the relationship between variables. Regarding that the type of all variables was interval, correlation analysis was selected and after checking the normality of variables, Pearson's method was applied. The result is reported in Table 1.

\section{Table1 Correlation Matrix}

\begin{tabular}{|c|c|c|c|c|}
\hline & & Innovation & SHRM & Firm Performance \\
\hline \multirow{4}{*}{ Innovation } & Pearson Correlation & 1 & & \\
\hline & Sig. (2-tailed) & & & \\
\hline & $\mathrm{N}$ & 54 & & \\
\hline & Pearson Correlation & $.986^{* *}$ & 1 & \\
\hline \multirow[t]{3}{*}{ SHRM } & Sig. (2-tailed) & .000 & & \\
\hline & $\mathrm{N}$ & 54 & 54 & \\
\hline & Pearson Correlation & $.979^{* *}$ & $.975^{* *}$ & 1 \\
\hline \multirow[t]{2}{*}{ Firm Performance } & Sig. (2-tailed) & .000 & .000 & \\
\hline & $\mathrm{N}$ & 54 & 54 & 54 \\
\hline
\end{tabular}

\section{1- Findings and Discussion}

Assessment of the correlation matrix reveals that:

1- Strategic human resource management is positively correlated and this correlation is strong and statistically significant $(\mathrm{r}=0.986, \mathrm{p}=.000)$. So, the null hypothesis is rejected and our first hypothesis is accepted.

2- Innovation and firm's overall performance are positively correlated and this correlation is strong and statistically significant $(\mathrm{r}=0.979, \mathrm{p}=.000)$. So, the null hypothesis is rejected and hypothesis 2 is accepted.

3- Strategic human resource management and firm's performance are positively correlated and this correlation is strong and statistically significant $(\mathrm{r}=0.975, \mathrm{p}=.000)$.Consequently, the null hypothesis is rejected and hypothesis 3 is accepted.

The results of the analysis clearly show that all the three variables are positively and strongly correlated. This means that whenever one of the variables increases, the other two variables increase and vise versa. For example, if strategic human resource management is strengthened in a firm, an improvement in innovative activities and the firm's overall performance is expectable.

\section{IMPLICATIONS}

The strong link between SHRM, innovation, and firm performance suggests the idea that implementation of a strong SHRM system can lead the firm toward successful innovation practices and an acceptable overall performance. In other words, strategic human resource management facilitates innovative activities and consequently improve the firm's performance. This could be an important implication of the current study's findings. In other words, if managers and entrepreneurs want to improve their firms' performance and survive in the competitive market by taking innovation as their business strategy, they should create the culture of strategic thinking in their HRM departments and facilitate implementation of SHRM systems.

\section{CONCLUSION}

In a rapidly changing environment and competitive market, innovation is the most important source of competitive advantage. Innovative activities within a firm, highly depends on its human resource capitals. HR systems by developing the core competencies of a firm can contribute to achieving high organizational and market performance. Strategic nature of innovative activities requires the development of strategic thinking in HR activities.

This paper tried to find a linkage between SHRM, innovation, and overall performance of firms. An online survey participated by the managers of product development projects in Malaysian manufacturing companies provided required data to examine this idea. Correlation analysis of collected data proved that the three mentioned variables are strongly correlated. This finding suggested the idea that implementation of a strong SHRM system within a firm can guarantee successful innovation practices as well as desirable overall performance. 


\section{REFERENCES}

[1] Eslami, N., \& Nakhaie, H. (2011), Effects of Human Resource Management Activities to Improve Innovation in Enterprises.

[2] Chen, C. J., \& Huang, J. W. (2009). Strategic human resource practices and innovation performance-The mediating role of knowledge management capacity. Journal of Business Research, 62(1), 104-114.

[3] Montes, F. J. L., Moreno, A. R., \& Fernández, L. M. M. (2004). Assessing the organizational climate and contractual relationship for perceptions of support for innovation. International Journal of manpower, 25(2), 167-180.

[4] Downes, L., \& Nunes, P.F (2013), Big-Bang disruption. Harvard business review.

[5] Youndt, M. A., Snell, S. A., Dean Jr, J. W., \& Lepak, D. P. (2006). Human resource management, manufacturing strategy, and firm performance. Academy of management Journal, 836-866.

[6] Sharma, S. (2012). Role of innovation and strategic human resource management in business development. ZENITH International Journal of Business Economics \& Management Research Vol.2 Issue 1

[7] ÇALIŞKAN, E. N. (2010). The impact of strategic human resource management on organizational performance. Journal of Naval Science and Engineering, 6(2), 100-116.

[8] Scarbrough H.(2003). Knowledge management, HRM and the innovation process. Int J Manpow 2003 24(5):501-16.

[9] Collins, C. J., \& Clark, K. D. (2003). Strategic human resource practices, top management team social networks, and firm performance: The role of human resource practices in creating organizational competitive advantage. Academy of Management Journal, 46(6), 740-751.

[10] Laursen, K., \& Foss, N. J. (2003). New human resource management practices, complementarities and the impact on innovation performance.Cambridge Journal of economics, 27(2), 243-263.

[11] Madsen, A. S., \& Ulhøi, J. P. (2005). Technology innovation, human resources and dysfunctional integration. International Journal of Manpower, 26(6), 488-501.

[12] Jaw, B. S., \& Liu, W. (2003). Promoting organizational learning and self-renewal in Taiwanese companies: The role of HRM. Human Resource Management,42(3), 223-241.

[13] Mumford MD. (2000). Managing creative people: strategies and tactics for innovation.Hum Resour Manage 10(3):313-51.

[14] Weisberg RW. (2006). Expertise and reason in creative thinking: evidence from case studies and the laboratory. In: Kaufman JC, Baer J, editors. Creativity and Reason in Cognitive Development. Cambridge: Cambridge University Press.

[15] Torraco RJ, Swanson RA.(1995). The strategic roles of human resource development.Hum Resour Plann 18(4):10-21.

[16] Jiménez-Jiménez D, Sanz-Valle R. (2005). Innovation and human resource management fit: an empirical study. Int J Manpow 26(4):364-81.

[17] Yilmaz, C., Alpkan, L., Ergun, E., (2005). Cultural determinants of customer-and learning-oriented value systems and their joint effects on firm performance. Journal of Business Research 58,1340-1352.

[18] Walker, R.M., 2004. Innovation and organizatonal performance: Evidence and a research agenda. Advanced Institute of Management Research Working Paper, WP No: 002-June.

[19] Wu, F., Mahajan, V., Balasujbramanian, S., (2003). An analysis of e-business adoption and its impact on business performance. Journal of the Academy of Marketing Sciences 31, 425-447.

[20] Chandler, G.N., Hanks, S.H., (1994). Market attractiveness, resource-based capabilities, venture strategies, and venture performance. Journal of Business Venturing 9 (4), 331-349.

[21] Subramanian, A., \& Nilakanta, S. (1996). Organizational innovativeness: exploring the relationship between organizational determinants of innovation, types of innovations, and measures of organizational performance. Omega,24(6), 631-647.

[22] Miller, W.L.,(2001). Innovation for business growth. Research Technology Management 44 (5), 26-41.

[23] Gunday, G., Ulusoy, G., Kilic, K., \& Alpkan, L. (2011). Effects of innovation types on firm performance. International Journal of Production Economics, 133(2), 662-676.

[24] Guan, J. Ma, N., (2003). Innovative capability and export performance of Chinese firms. Technovation 23, $737-747$.

[25] Lin, C.Y., Chen, M.Y. ,(2007). Does innovation lead to performance? An empirical study of SMEs in Taiwan. Management Research News 30 (2), 115-132.

[26] Johne, A., Davies, R., (2000). Innovation in medium-sized insurance companies: how marketing adds value. International Journal of Bank Marketing 18 (1) 6-14.

[27] Oke, A., (2007). Innovation types and innovation management practices in service companies.International Journal of Operations and Production Management, 27 (6), 564-587.

[28] Noe,R., Hollenbeck,J., Gerhart,B., and Wright,P. (2007) Human Resources Management: Gaining A Competitive Advantage, 5th.Ed.,Mc-Graw-Hill Co. New York.

[29] Darwish,T.K. (2009). The Impact of Strategic Human Resource Management Implementation on Firm Performance. BBS Doctoral Symposium.

[30] Delery, J. E., \& Doty, D. H. (1996). Human Modes of theorizing in human resource management: Tests of universalistic, contingency, and configurations. Academy of management Journal, 39(4), 802-835.

[31] Jing, W. Huang, T. (2005) Relationship between Strategic Human Resources Management and Firm Performance, International Journal of Manpower, pp. 434-449. 